\title{
Mineral chemistry of tourmaline from Mashak Pahar, South Purulia Shear Zone (SPSZ), eastern Indian Shield
}

\author{
Santanu Acharjee ${ }^{1}$, Jyotisankar Ray ${ }^{1, *}$, Payel Dey ${ }^{1}$, Debapriya Bhattacharyya ${ }^{1}$, \\ Mousumi Banerjee ${ }^{1}$, Basab Chattopadhyay ${ }^{2}$, Shyamal Sengupta ${ }^{2}$, A K Bhatt ${ }^{3}$, \\ D Chowdhury $^{3}$, A K Dwivedi ${ }^{3}$, Sanjoy Mahato ${ }^{1}$, Arka Ranjan Jana ${ }^{1}$, P B Maithani ${ }^{3}$ \\ and P V RAMESH BABU ${ }^{3}$ \\ ${ }^{1}$ Department of Geology, University of Calcutta, 35 Ballygunge Circular Road, Kolkata 700 019, India. \\ ${ }^{2}$ Central Petrological Laboratories, Geological Survey of India, $15 \mathrm{~A} \& \mathrm{~S}$ B, Kyd Street, Kolkata 700 016, India. \\ ${ }^{3}$ Atomic Minerals Directorate for Exploration and Research, Department of Atomic Energy, Hyderabad, India. \\ ${ }^{*}$ Corresponding author.e-mail: jsray65@hotmail.com
}

The area of investigation at and around Mashak Pahar, Bankura district, West Bengal, India comprises a number of rock types namely: granite gneiss, migmatized quartz tourmaline gneiss, quartz pebble conglomerate, ferruginous quartzite, quartz tourmaline veins (as veins) and graphite schists. Interestingly, the study area lies in the region extending South Purulia Shear Zone ( Tamar-Porapahar Shear Zone) which marks the boundary between two contrasting tectonic blocks of eastern India, namely, the Chhotanagpur Gneissic Terrane (CGC) to the north and Singhbhum Group of rocks to the south. The rocks of the study area are poly-phasedly deformed by three phases of folding, namely, $\mathrm{F}_{1}, \mathrm{~F}_{2}$ and $\mathrm{F}_{3}$. All the tourmalines are classified to be of 'Alkali Group'. Chemistry of tourmalines from migmatized quartz tourmaline gneiss and those from quartz tourmaline veins are in conformity with their relation to (earthquake induced) shear system evolution in this terrain. In general, the compositional evolution of tourmaline during prograde metamorphism $\left(\sim 400^{\circ}-730^{\circ} \mathrm{C}\right)$ has been supported by both petrographic and chemical evidences. Assessment of mineral-chemical data of constituent tourmaline grains clearly suggests compositional variations across zonal boundaries within tourmaline that was controlled by changing metamorphic milieu in this terrane. Field and petrographic evidences clearly indicate activation of earlier and later shears in this region accompanied by infiltration of boron and formation of zoned tourmaline crystals.

\section{Introduction}

Minerals of the tourmaline group have been studied extensively because of their complex composition, structure and importance as petrologic and metallogenic indicators. Their systematic compositional variations are related to the $\mathrm{P}-\mathrm{T}-\mathrm{X} /\left(\mathrm{O}_{2}\right)$ conditions of the environment of crystallization and also interactions with the host rocks (Henry and Guidotti 1985; Fareeduddin et al. 2010). The geothermobarometric potential of tourmaline has been accessed by elemental exchange among tourmaline and coexisting minerals in metamorphosed pellites and greywakes. The evidence of such elemental exchange between tourmaline and other associated minerals has been documented both

Keywords. South Purulia Shear Zone; tectonic block of eastern India; shear zone; poly-phased deformation; tourmaline chemistry; boron infiltration. 
from natural sample as well as experimental data. The potential of this tourmaline geothermobarometry has not gained enough acceptance in view of the variable and unpredictable nature of elemental distribution among different structural sites of tourmaline which in turn distorts KD vs. T relation (Hinsberg and Schumacher 2009). In different parts of the world, tourmalines have been reported in several litho-associations (Harraz and El-Sharkawy 2001). Commonly, tourmaline occurrences have been reported from metapelitic schists, leucocratic granitoids and pegmatoids. In fact, tourmaline is the important $\mathrm{Fe}-\mathrm{Mg}$ mineral in the leuco-granite and pegmatite and occurs as distinctly large crystal in the host crystalline rocks or these are associated with folded host rocks (Gaweda et al. 2002). Very often tungsten and boron in quartz vein deposits are remobilized from strata-bound scheelite and tourmalinite, dominantly by liquid-state transfer associated with regional shear zone.

The investigated area at and around Mashakpahar (covering latitude $22^{\circ} 58^{\prime} 56^{\prime \prime}-22^{\circ} 58^{\prime} 8.3^{\prime \prime} \mathrm{N}$ and longitude $86^{\circ} 52^{\prime} 33.8^{\prime \prime}-86^{\circ} 53^{\prime} 35.8^{\prime \prime} \mathrm{E}$ ) Bankura district, West Bengal, India, comprises of a number of rock types namely granite gneiss, migmatized quartz tourmaline gneiss, quartz pebble conglomerate, quartz tourmaline veins and graphite schists. The area is located in the region extending South Purulia Shear Zone (SPSZ) (also known as Tamar Porapahar Shear Zone) which marks the boundary between the Chhotanagpur Gneissic Complex (CGC) and Singhbhum Group of rocks in the eastern Indian shield. This paper describes the occurrence of tourmaline associated with (i) migmatized granite gneiss and (ii) quartz veins occurring along the SPSZ.

\section{Geological background}

The Eastern Indian Shield constitutes an ancient cratonic block, recording geological event of age ranging from early Archean to late Proterozoic (Saha 1988). This cratonic block is one of the earliest Archean nuclei around which the continental crust of Indian Shield has grown (Sarkar and Saha 1997). The cratonic block is made up of a central batholithic complex of Singhbhum granite and other granites of different ages and enclaves of metasediments, metabasics and contain supracrustal belt of volcano-sedimentary rocks (Sarkar and Saha 1983). The craton is bounded by an arcuate thrust zone in the north, called Singhbhum Shear Zone (SSZ) or Singhbhum copper belt thrust. Regional geological overview (surrounding

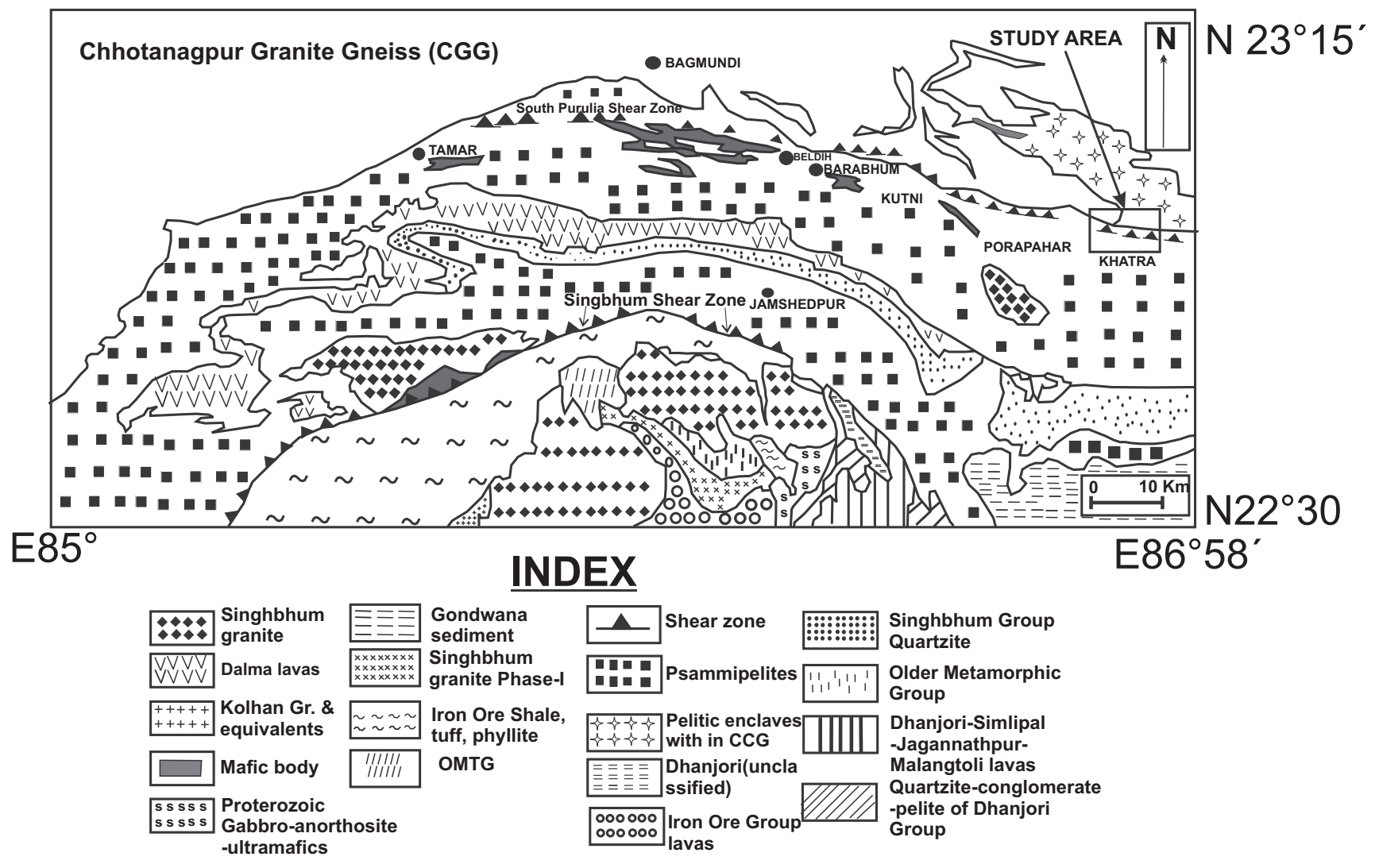

Figure 1. Geological map of the Singhbhum-North Orissa region after Saha (1994). 
the study area) is given in figure 1. This figure shows that the high grade CGC is separated from the rocks of the Singhbhum Group and the separating boundary between these two terranes (CGC and rocks of Singhbhum Group) is marked by a zone of intense brittle-ductile shear known as South Purulia Shear Zone (SPSZ). This shear zone in the literature is also known as Tamar-Porapahar Shear Zone (Mahadevan 1992). The disposition of SPSZ is roughly parallel to SSZ (Kumar and Dasgupta 1985). Because of structural intricacy and mineralization potential, SPSZ has been the centre of attraction by many researchers (Das 1977; Sarkar 1977; Baidya and Chakravarty 1988; Sarkar et al. 1993; Dasgupta et al. 2000; Som et al. 2002).

The study area has undergone several phases of deformation and metamorphism. The details are given below.

\section{Structural geology and shear manifestation in the study area}

Figure 2 shows the geological map of the investigated area. The study area had suffered poly-phased deformation, which is evident from three different phases of folding. The first deformation produced the first fold $\left(F_{1}\right)$ in the area. It is represented by relict rootless intrafolial isoclinal folds developed on primary compositional layering $\left(\mathrm{S}_{0}\right)$. The pervasive earlier set of foliation plane $\left(\mathrm{S}_{1}\right)$ is axial planar to $\mathrm{F}_{1}$ (figure 3). The subsequent deformation folded the $S_{1}$ foliation and gives rise to the second generation fold $\left(\mathrm{F}_{2}\right)$. The latter set of foliation plane $\left(\mathrm{S}_{2}\right)$ planar structure (parallel to the axial plane of $\mathrm{F}_{2}$ fold) was later folded by another deformation causing the third fold $\left(\mathrm{F}_{3}\right)$. Pucker axis lineation is observed in graphite schist and quartz pebble conglomerate, though their frequency is very low. The linear structure in the area happens to be controlled by fold axis of $\mathrm{F}_{2}$. Thus, they are assumed to be pre- $\mathrm{F}_{2}$ and related to $\mathrm{F}_{1}$.

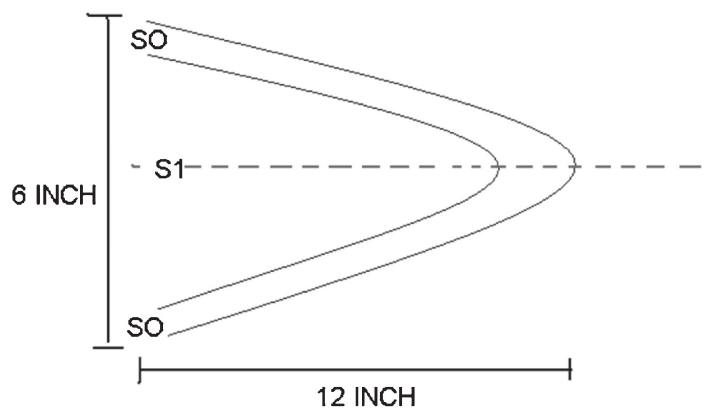

Figure 3. Sketch showing axial trace of earliest rootless isoclinal fold developed on primary compositional layer $\left(\mathrm{S}_{0}\right)$. $\mathrm{S}_{1}$ is axial planar to $\mathrm{F}_{1}$ (plan view). $\mathrm{S}_{1}$ : Earlier set of foliation plane, $F_{1}$ : Earliest (first) fold. For details see text.

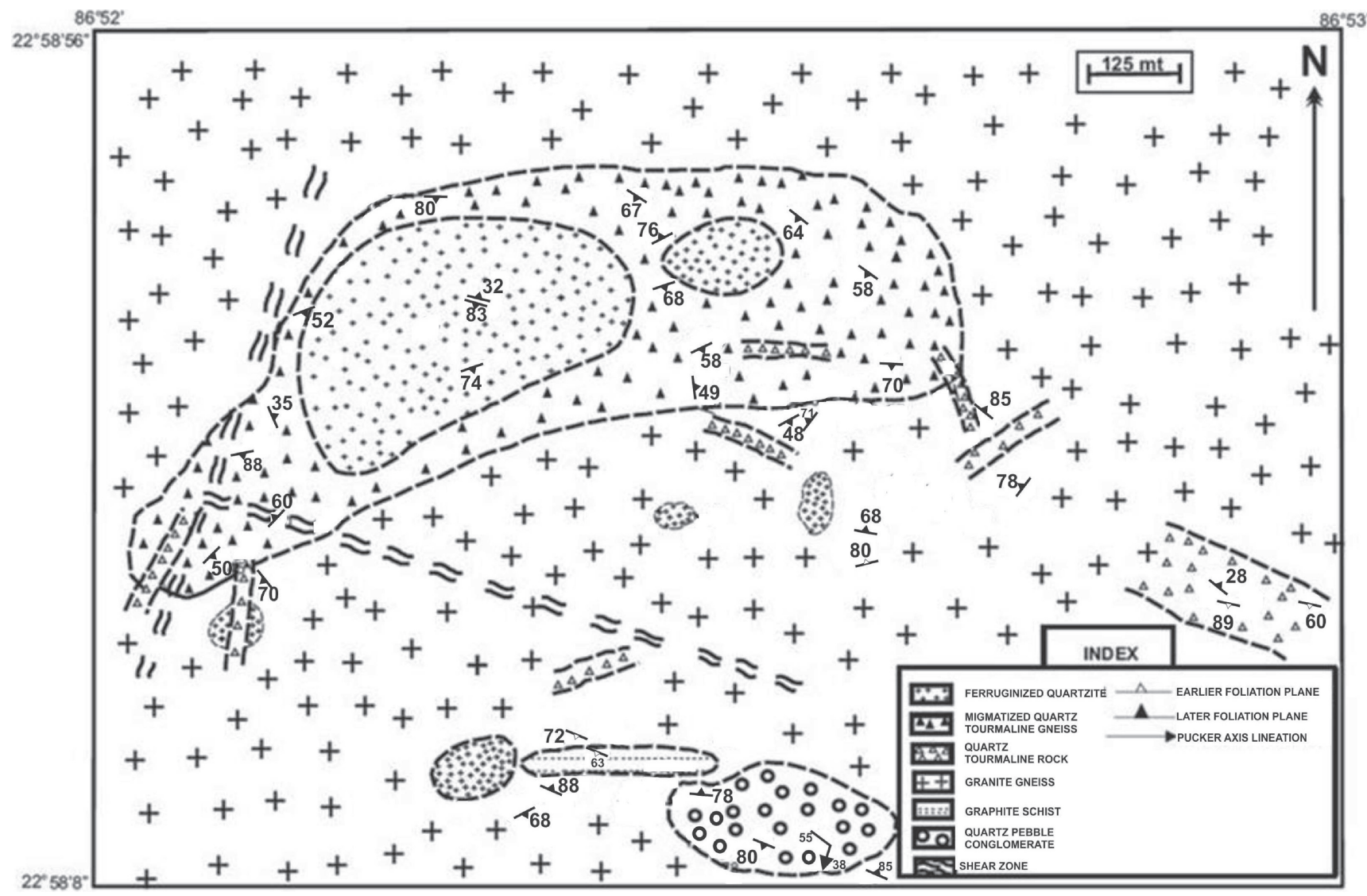

Figure 2. Geological map of the investigated area. 
The mapped area (figure 2) shows development of number of shear zones and the study area lies in the regionally developed Tamar-Porapahar Shear Zone or South Purulia Shear Zone (figure 1). The investigated area reveals two extensive shear planes along with the presence of some locally developed ones. Very often, the shear planes allow easy access of boron to give rise to tourmaline bearing rock types (Mc Caig 1989). Several distinct evidence of shearing, viz., grain-subgrain relation, pseudotachylite, quartz ribbon formation and undulose extinction are common (White et al. 1980; Urai and Humphreyes 1981; Kerrich 1986; Numan and Tracy 1993). Incidentally, ubiquitous presence of pseudotachylite in almost all the rock types indicates effects of shearing (Thorpe 1987; Leech et al. 2009) or shearing-induced earthquake (Freund et al. 2007). The disposition of the shear zones in the area (figure 2) clearly suggests that those were mostly developed after all the folding phases were over. The migmatite rock of the study area contains shear induced, small, thin, vein-like tourmalines parallel to the foliation plane of migmatite. It has also been observed that foliation planes in migmatite are controlled by $F_{1}$, so we suggest that one set of shear planes might have been formed during or immediately after $\mathrm{F}_{1}$ (noting the presence of tourmaline in the migmatized quartz tourmaline rock). Strata bound tourmaline occurs in a sizeable amount in migmatized quartz tourmaline gneiss and ferruginized quartz tourmaline veins, whereas in graphite schist and in quartz pebble conglomerate, the amount of strata bound tourmaline is very small. In quartz-tourmaline veins (embodying development of later-generation tourmalines), the amount of modal tourmaline is also pronounced (ranging as high as 86.5 vol\%).

\section{Petrography}

The investigated area reveals the following lithotypes mainly granite gneiss, ferruginous quartzite, graphite schist, quartz pebble conglomerate, migmatized quartz tourmaline gneiss and quartz tourmaline vein. The granite gneiss is leucocratic, coarse grained, mainly equigranular with moderate specific gravity and it consists of alternate bands of felsic and mafic minerals (figure 4a). Ferruginous quartzite lithotype is typically composed of quartz grains with occasional presence of tourmaline and epidote and presence of pseudotachylite (figure 4b). Ferrugination of variable degrees has been noticed and this shows pinch and swell structure (figure 4c). Graphite schists is characterized by well-defined compositional layers manifested in terms of different colour bandings; a pervasive schistosity has been imposed in this rock type (figure 4d). Quartz pebble conglomerate macroscopically consists mainly of quartz pebbles some of which are angular (figure 4e). There is a sharp size variation of pebbles within this rock. Macroscopically, migmatized quartz tourmaline gneiss appears to be extremely foliated with presence of alternate dark and light coloured bands (figure 4f). The migmatitic nature of the rock has been marked by leucosome (composed of quartz and feldspar grains) and melanosome (composed of fine-grained tourmaline and relatively small amount of biotite) (figure $4 \mathrm{~g}$ ). The rock shows two types of tourmaline grains. The first type is marked by prominent euhedral tourmaline, while the other type is represented by elongated subhedral medium-sized tourmaline. Both the types show inclusion of quartz defining poikiloblastic texture (figure $4 \mathrm{~h}$ ). Quartz grains show undulose extinction, effect of recrystallization, sutured contact and ribbon like appearance (figure $4 \mathrm{i}$ ). It is an important point to note that the tourmaline grains occurring in the migmatized quartz tourmaline rocks are compositionally zoned implying their growth corresponding to different prograde metamorphic conditions (details are given in later sections). Further, tourmaline development due to boron movement following easy passage of shear planes (sometimes aided by regional metamorphism) is a common phenomenon and has been reported from many parts of the world by several researchers (London 1986; London et al. 1988; Dutrow et al. 1999; Sengupta et al. 2005). The quartz tourmaline veins, on the other hand, in the field, are found to occur as distinct intrusions into the surrounding migmatized quartz tourmaline gneiss (figure $4 \mathrm{j}$ ). These rocks are mesocratic, medium- to coarse-grained with moderate specific gravity. Microscopically, the rock shows xenomorphic granular texture; quartz inclusions within tourmaline grains have also been recorded. Occurrence of tourmaline at the margin of biotite indicates that tourmaline has formed on consumption of biotite (figure $4 \mathrm{~h}$ ). Zoning in tourmaline in this rock type is very much well defined, suggesting its growth under different metamorphic conditions (figure $4 \mathrm{k}$ ). The associated quartz grains somewhere shows undulose extinction, polygonization and local grain suturing indicating minor effect of shearing. Pseudotachylite is characteristically found in granite gneiss, migmatized quartz tourmaline gneiss and quartz tourmaline vein which suggest their involvement with shear zone (figure 4l). Tourmaline grains, in migmatized quartz tourmaline gneiss typically follow overall foliation plane present in this rock ( $\sim$ syntectonic); while tourmaline grains that are found in quartz tourmaline veins appear to be post-tectonic, controlled by boron infiltration. Representative modal data of lithotypes have been furnished in tables 1 and 2 . 

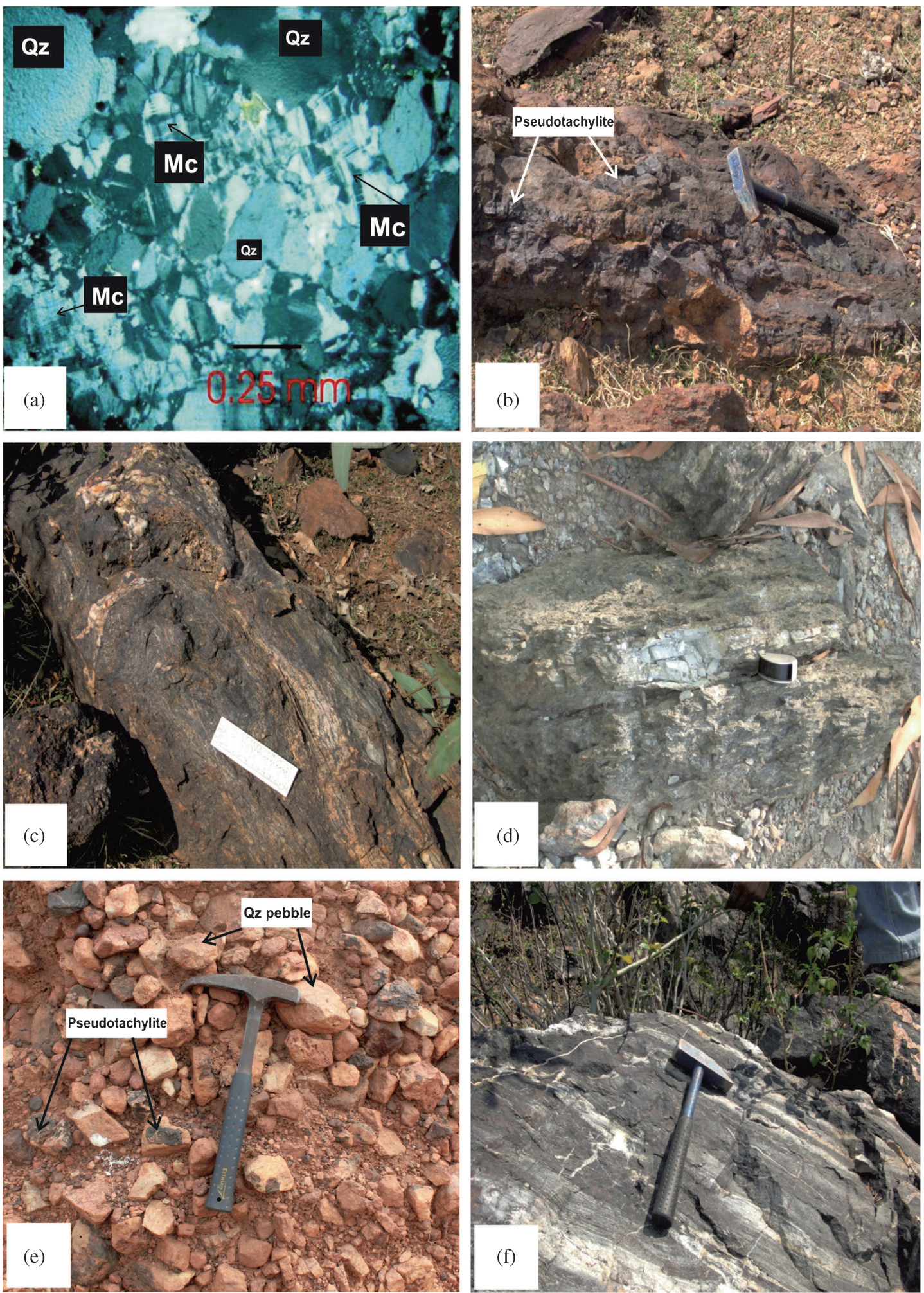

Figure 4. (a) Photomicrograph showing effects of re-crystallization in granite gneiss (Qz=Quartz, Mc= Microcline). (b) Well developed colour variation in ferruginous quartzite with presence of minor pseudotachylite. (c) Field photograph showing pinch and swell structure and folded layers of quartz within ferruginous quartzite. (d) Field photograph showing well foliated graphite schist. (e) Exposure of shear-controlled quartz pebble conglomerate. (f) Field photograph of well-developed gneissosity in migmatized quartz tourmaline gneiss. (g) Photomicrograph showing well developed gneissic foliation in migmatized quartz tourmaline in plane polarized light. (h) Photomicrograph showing presence of two sets of tourmaline grains. Tourmaline occurs in the periphery of biotite (Tur = tourmaline, Bt = biotite, Qz = quartz). (i) Photomicrograph showing ribbon quartz in migmatized quartz tourmaline gneiss. (j) Field photograph showing quartz tourmaline veins. (k) Photomicrograph showing strong zoning of tourmaline crystals in quartz tourmaline vein. (l) Photomicrograph showing presence of pseudotachylite in quartz pebble conglomerate. 

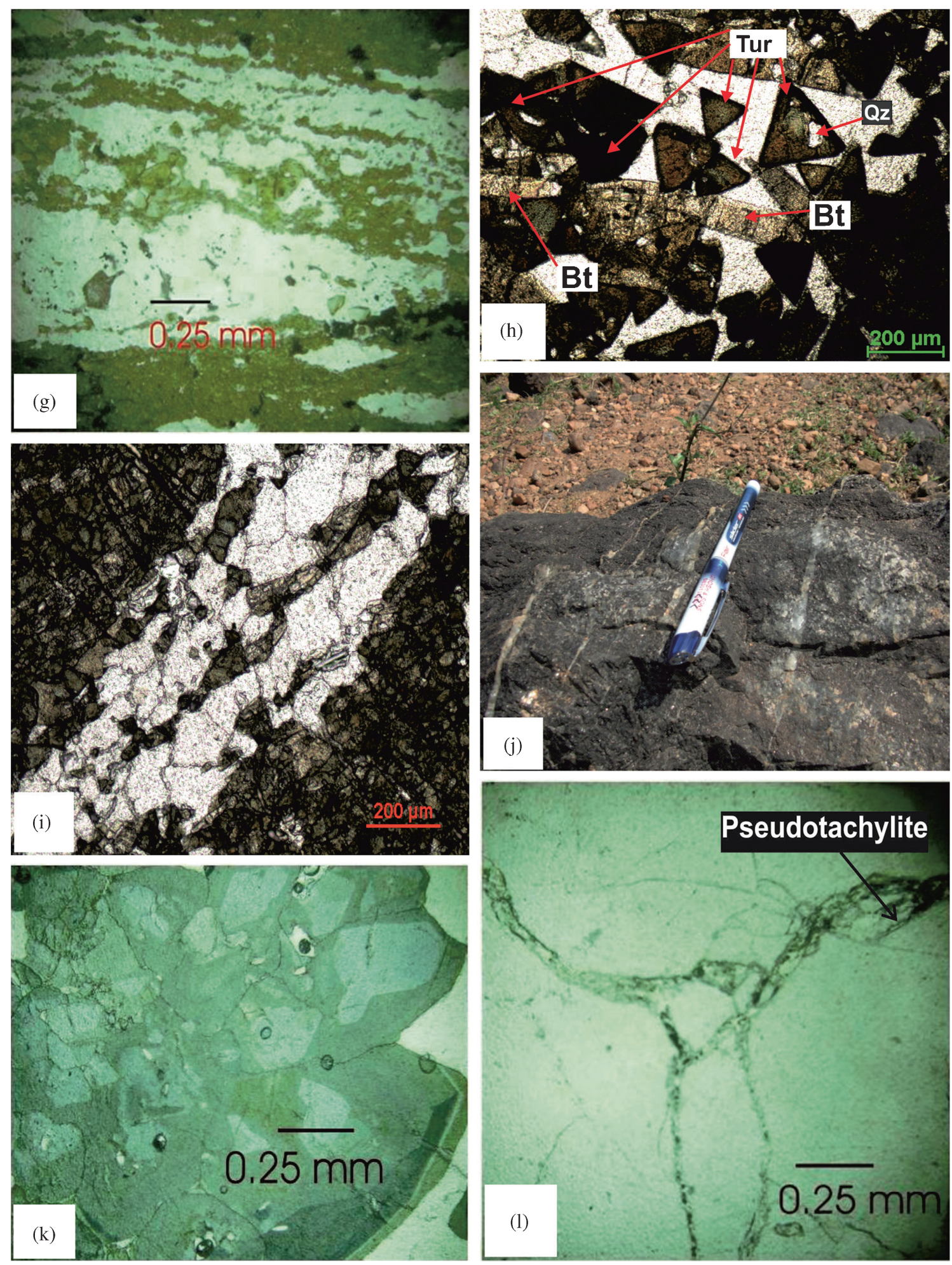

Figure 4. (Continued.)

5. Chemistry of tourmaline and other mineral phases

Mineral-chemical data of the important mineral phases, namely, tourmaline, biotite, muscovite, plagioclase and K-feldspar have been presented in tables 3-5. The electron microprobe analyses of constituent mineral phases were done at the Geological Survey of India, Central Petrological Laboratory, Kolkata, using an automated Electron Probe Micro Analyzer (SX 100 Cameca) operating at an accelerating voltage of $15 \mathrm{kV}$ and 
Table 1. Modal data of granite gneiss (vol\%).

\begin{tabular}{lccccc}
\hline Sp. no. & 8 & 116 & 106 & $117 \mathrm{~B}$ & 37 \\
\hline Quartz & 78.68 & 58.58 & 68.66 & 72.12 & 50.93 \\
Altered alkali feldspar & - & 24.58 & 14.93 & 18.73 & 33.46 \\
Plagioclase & 0.84 & - & - & - & - \\
Orthopyroxene & 7.62 & - & 0.53 & - & - \\
Biotite & 2.68 & 2.33 & - & 0.45 & 3.86 \\
Pseudotachylite & 0.98 & - & - & 1.24 & 2.53 \\
Microcline & 0.14 & - & - & - & - \\
Perthite & 5.92 & - & 4.0 & - & - \\
Apatite & 0.77 & - & 0.26 & 0.45 & - \\
Muscovite & 2.04 & 11.5 & 10.13 & 4.40 & 7.86 \\
Ferruginous alteration & 0.28 & 1.25 & 0.26 & - & - \\
Opaque & - & 1.75 & - & - & - \\
Garnet & - & - & - & 0.22 & - \\
Tourmaline & - & - & 1.06 & 0.79 & - \\
Epidote & - & - & 0.13 & 1.58 & 1.33 \\
\hline
\end{tabular}

Table 2. Modal data of migmatized quartz tourmaline gneiss and quartz tourmaline veins (vol\%).

\begin{tabular}{|c|c|c|c|c|c|c|c|}
\hline \multirow{2}{*}{$\begin{array}{l}\text { Rock types } \\
\text { Sp. no. }\end{array}$} & \multicolumn{2}{|c|}{$\begin{array}{c}\text { Migmatized } \\
\text { quartz-tourmaline gneiss }\end{array}$} & \multicolumn{5}{|c|}{ Quartz-tourmaline veins } \\
\hline & 125 & 101 & 11 & 34 & $9 \mathrm{~A}$ & 113 & 114 \\
\hline Quartz & 42.6 & 70.53 & 73.87 & 56.53 & 69.63 & 85.46 & 12.35 \\
\hline Tourmaline & 48.4 & 25.2 & 24.73 & 37.8 & 26.88 & 12.33 & 86.5 \\
\hline Pseudotachylite & 3.8 & 2.9 & 0.8 & 5.46 & 3.31 & 1.6 & 0.85 \\
\hline Epidote & 0.46 & 1.13 & - & 0.13 & 0.16 & 0.26 & - \\
\hline Garnet & 0.8 & 0.06 & - & 0.06 & - & - & - \\
\hline Biotite & 0.2 & - & 0.46 & - & - & - & - \\
\hline Muscovite & - & - & - & - & - & 0.13 & - \\
\hline Opaque & 0.06 & - & - & - & - & - & - \\
\hline Perthite & 2.13 & - & - & - & - & - & - \\
\hline Fe-alteration & 1.5 & 0.13 & 0.13 & - & - & 0.2 & 0.28 \\
\hline
\end{tabular}

beam current of $12 \mathrm{nA}$. Both synthetic and natural standards were used. Chemical composition of tourmaline grains of the study area from different litho-types, viz., migmatized quartz tourmaline gneiss (sp. nos. 101 and 55), quartz tourmaline vein (sp. no. 90) and quartz pebble conglomerate (sp. no. 40B) have been presented in table 3 . The atomic formula for the tourmaline was calculated using the method of Hawthorne and Henry (1999) assuming $\mathrm{B}=3$ in the formula unit. The tourmaline compositions from all the lithotypes (table 3 ) have been plotted in the triangular diagram $\mathrm{Ca}^{-}$ Cation vacancy- $-\mathrm{Na}+\mathrm{K}$ ) (figure 5) (advocated by Hawthorne and Henry 1999). The analyzed plots of all the tourmaline from different lithotypes fall in the 'Alkali Group' (figure 5). Hawthorne and Henry (1999) have classified tourmaline on the basis of $\mathrm{X}_{\text {vacancies/(Na+Xvacancies) }}$ vs. $\mathrm{X}_{\mathrm{Mg}}$ diagram plots. The analyzed data of tourmalines when referred to such diagram fall in 'dravite' or 'schorl' fields (figure 6). This figure shows that the plots of tourmalines from migmatized quartz tourmaline gneiss mainly fall in the dravite field, while plots for quartz tourmaline veins mainly occupy schorl field (although there is a slight overlap of data). Plot of tourmaline from quartz pebble conglomerate also falls in dravite field (figure 6); it therefore clearly shows that there is a significant change of tourmaline compositions from dravite to schorl fields corresponding to migamtized quartz tourmaline gneiss and quartz tourmaline veins.

In order to understand variation of chemistry of the zoned tourmaline grains for both the quartztourmaline gneiss and quartz tourmaline veins, their elemental oxide variation patterns have been plotted in figure 7(a), (b) and 8(a) and (b), respectively. Figure 7(a) shows plots for zoned tourmaline chemistry, which comes from migmatized quartz tourmaline gneiss (sp. no. 101). This depicts a considerable variation of $\mathrm{FeO}$ and $\mathrm{MgO}$ contents from core to rim (peaks and valleys correspond to zonal boundaries within single grain). The overall 
表

نे

ठ்

ตี

青

రัن

灵

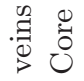
品莺 营

¿்

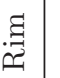

ㄴำ

N 0 至

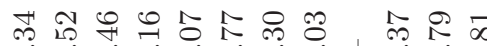

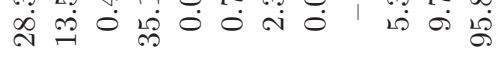

ํำ in

రัँ

为

กั่

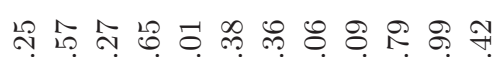

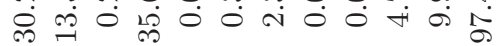

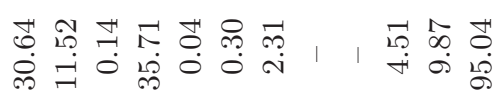

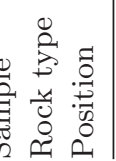

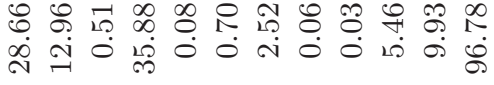

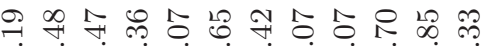

ลे

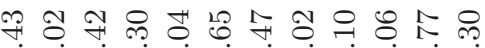

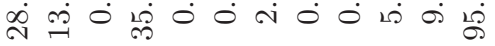

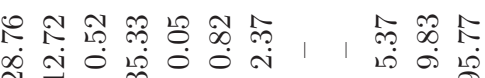

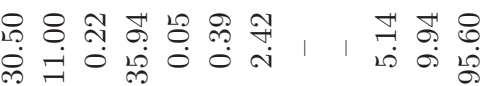

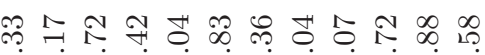

穴

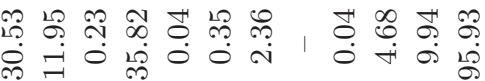

ஜำ

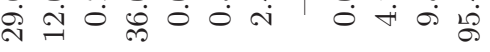

두

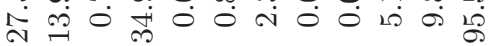


రั:

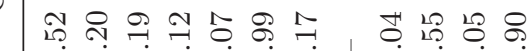

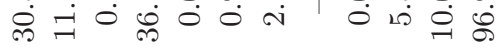

毒

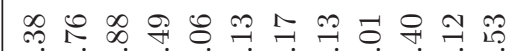

ठ்

表

章

ঠ் 员贯 :

:

के

ঠ்

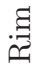

灵

节

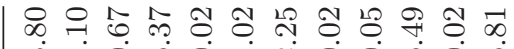

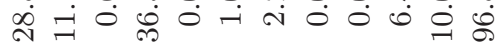

ర)

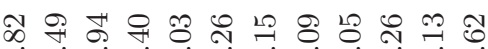

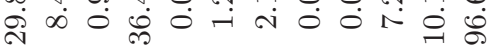

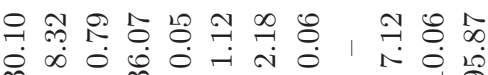

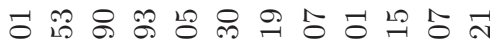

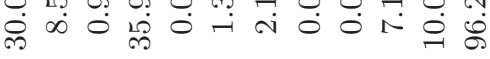

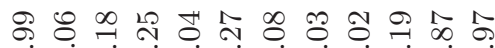

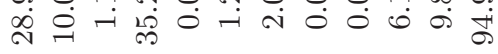

응ㅇㅇ 8 \&

बें 0 迥

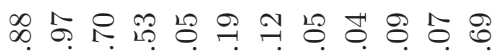

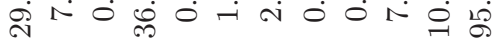

유 악

ते $\infty$ मn

:

妾

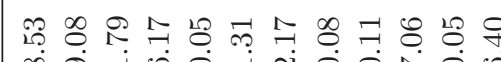

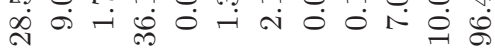

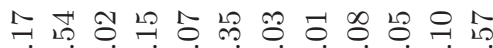

过 $\infty$ i

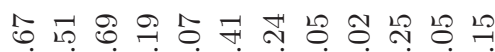

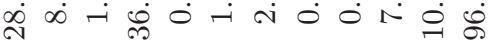

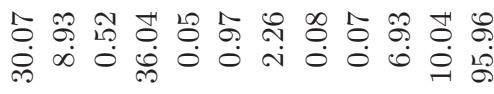

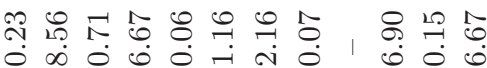

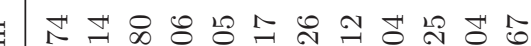

ठั

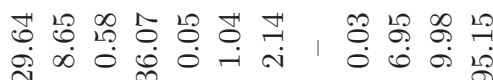

要

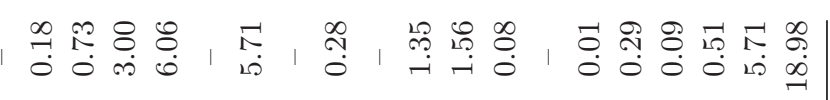

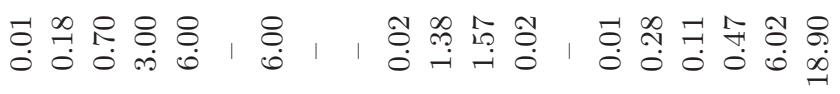

च

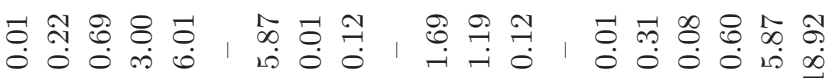

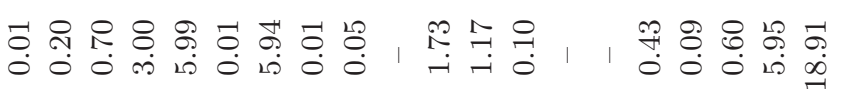

듀유 \& $\&$ \&

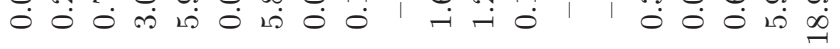

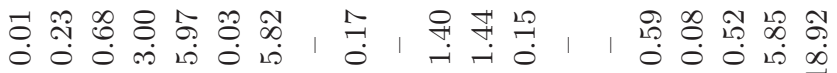

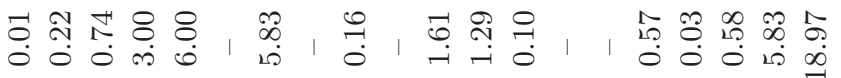

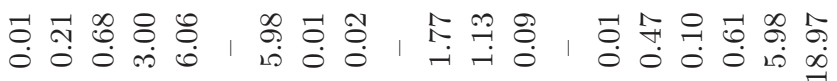

ప

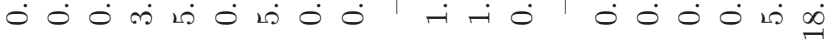

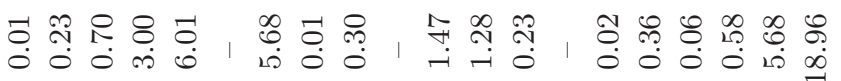

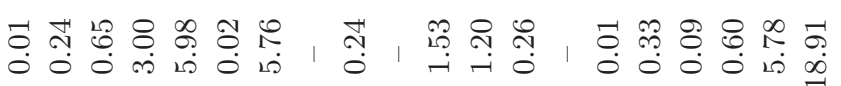

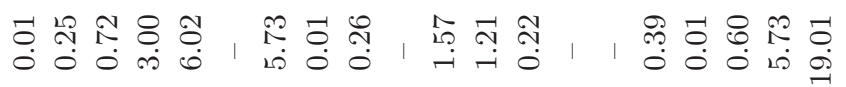

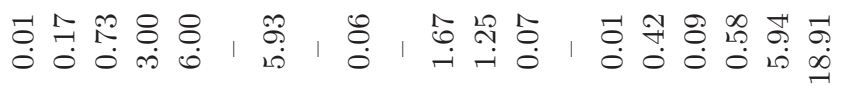
苛 府

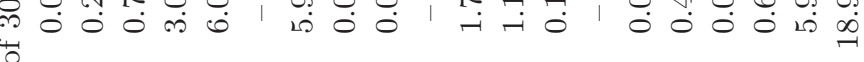

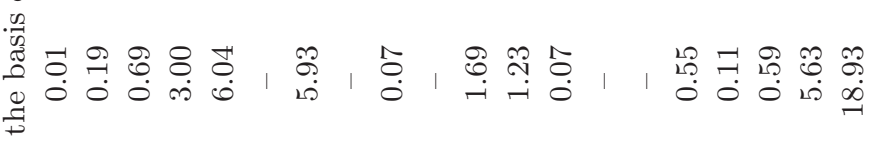
ธี

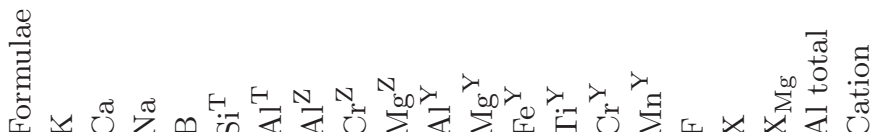




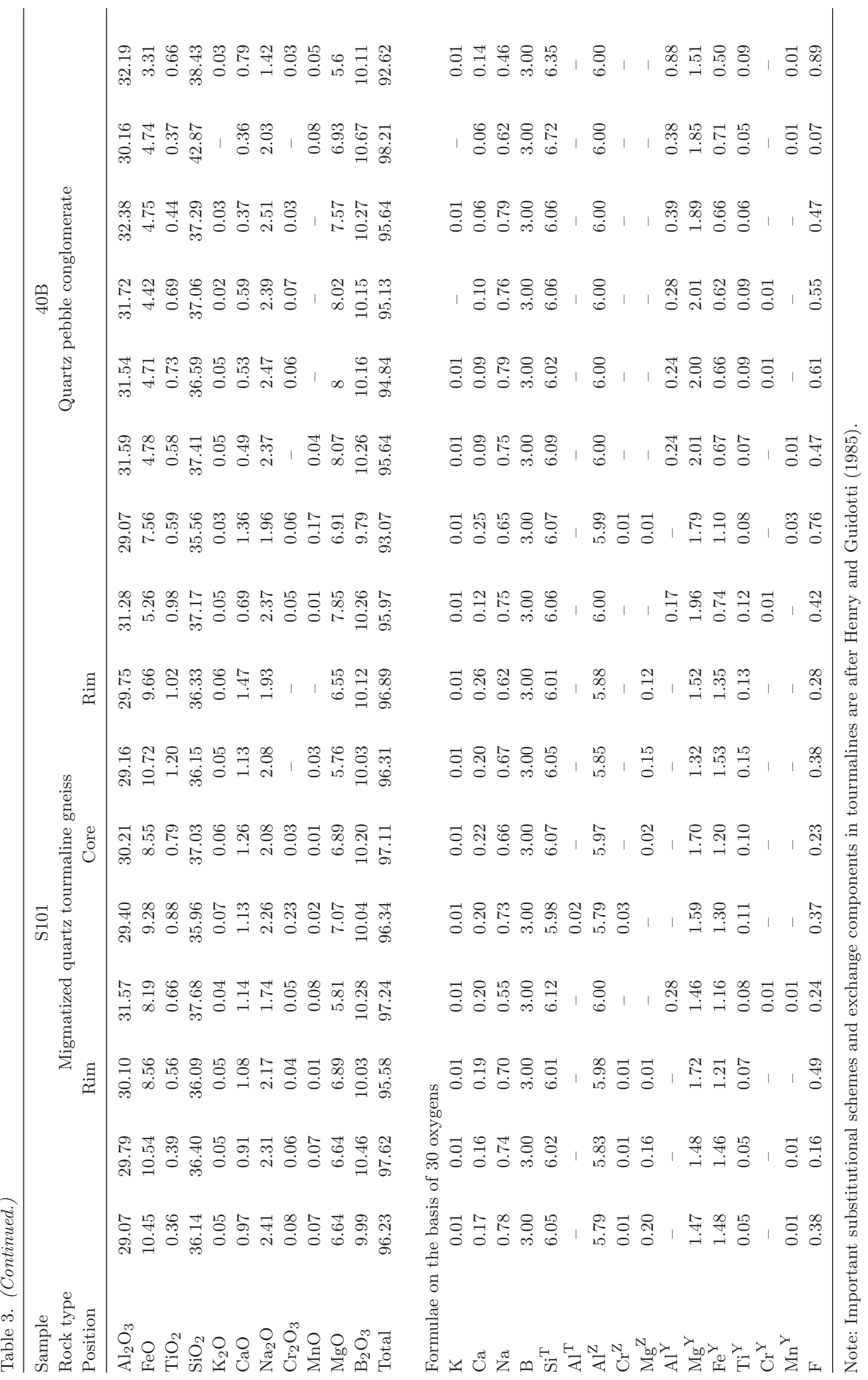


Table 4. Electron probe micro analyses of co-existing plagioclase and K-feldspar from granite gneiss, sp. no. 8.

\begin{tabular}{|c|c|c|c|c|c|}
\hline \multicolumn{3}{|c|}{ Plagioclase } & \multicolumn{3}{|c|}{ K-feldspar } \\
\hline Point & $35 / 1$ & $36 / 1$ & Point & $32 / 1$ & $33 / 1$ \\
\hline $\mathrm{Al}_{2} \mathrm{O}_{3}$ & 20.64 & 21.85 & $\mathrm{Al}_{2} \mathrm{O}_{3}$ & 17.98 & 18.45 \\
\hline $\mathrm{FeO}$ & 0.01 & 0.05 & $\mathrm{FeO}$ & 0.04 & 0.01 \\
\hline $\mathrm{TiO}_{2}$ & - & 0.01 & $\mathrm{TiO}_{2}$ & - & - \\
\hline $\mathrm{SiO}_{2}$ & 66.58 & 64.66 & $\mathrm{SiO}_{2}$ & 64.39 & 65.41 \\
\hline $\mathrm{K}_{2} \mathrm{O}$ & 0.08 & 0.08 & $\mathrm{~K}_{2} \mathrm{O}$ & 16.46 & 11.53 \\
\hline $\mathrm{CaO}$ & 1.72 & 3.15 & $\mathrm{CaO}$ & - & 0.05 \\
\hline $\mathrm{Na}_{2} \mathrm{O}$ & 10.56 & 9.88 & $\mathrm{Na}_{2} \mathrm{O}$ & 0.45 & 3.51 \\
\hline $\mathrm{Cr}_{2} \mathrm{O}_{3}$ & 0.03 & - & $\mathrm{Cr}_{2} \mathrm{O}_{3}$ & 0.05 & 0.01 \\
\hline $\mathrm{MnO}$ & 0.03 & - & $\mathrm{MnO}$ & 0.03 & - \\
\hline $\mathrm{MgO}$ & 0.02 & 0.01 & $\mathrm{MgO}$ & 0.01 & 0.01 \\
\hline Total & 99.67 & 99.69 & Total & 99.41 & 98.98 \\
\hline \multicolumn{6}{|c|}{ Formulae on the basis of 8 oxygens } \\
\hline $\mathrm{Al}$ & 1.07 & 1.14 & $\mathrm{Al}$ & 0.99 & 1.00 \\
\hline $\mathrm{Si}$ & 2.93 & 2.86 & $\mathrm{Si}$ & 3.00 & 3.00 \\
\hline K & - & - & K & 0.98 & 0.68 \\
\hline $\mathrm{Ca}$ & 0.08 & 0.15 & $\mathrm{Ca}$ & - & - \\
\hline $\mathrm{Na}$ & 0.9 & 0.85 & $\mathrm{Na}$ & 0.04 & 0.31 \\
\hline Cation & 4.99 & 5 & Cation & 5.01 & 4.99 \\
\hline $\mathrm{X}_{\mathrm{Ab}}$ & 0.92 & 0.85 & $\mathrm{X}_{\mathrm{Or}}$ & 0.96 & 0.68 \\
\hline $\mathrm{X}_{\mathrm{An}}$ & 0.08 & 0.15 & $\mathrm{X}_{\mathrm{Ab}}$ & 0.04 & 0.32 \\
\hline
\end{tabular}

Table 5. Electron probe micro analyses of biotite and muscovite. End member recalculation after Holdaway et al. (1988). \#8 is a granite gneiss and \#40B is a quartz pebble conglomerate.

\begin{tabular}{|c|c|c|c|c|c|c|c|c|}
\hline \multicolumn{4}{|c|}{ Biotite } & \multicolumn{5}{|c|}{ Muscovite } \\
\hline Sample \# & 8 & $40 \mathrm{~B}$ & $40 \mathrm{~B}$ & Sample \# & 8 & 8 & $40 \mathrm{~B}$ & $40 \mathrm{~B}$ \\
\hline Point \# & $34 / 1$ & $41 / 1$ & $42 / 1$ & Point \# & $37 / 1$ & $38 / 1$ & $39 / 1$ & $40 / 1$ \\
\hline $\mathrm{Al}_{2} \mathrm{O}_{3}$ & 14.69 & 15.01 & 15.88 & $\mathrm{Al}_{2} \mathrm{O}_{3}$ & 31.08 & 31.17 & 30.95 & 30.76 \\
\hline $\mathrm{FeO}$ & 18.25 & 20.19 & 18.02 & $\mathrm{FeO}$ & 1.79 & 2.01 & 4.64 & 4.15 \\
\hline $\mathrm{TiO}_{2}$ & 2.19 & 3.03 & 3.14 & $\mathrm{TiO}_{2}$ & 1.21 & 0.56 & 1.12 & 1.12 \\
\hline $\mathrm{SiO}_{2}$ & 37.00 & 36.48 & 37.13 & $\mathrm{SiO}_{2}$ & 47.59 & 47.45 & 45.92 & 45.73 \\
\hline $\mathrm{K}_{2} \mathrm{O}$ & 9.84 & 8.36 & 9.25 & $\mathrm{~K}_{2} \mathrm{O}$ & 11.07 & 11.01 & 10.78 & 10.97 \\
\hline $\mathrm{CaO}$ & - & 0.11 & 0.05 & $\mathrm{CaO}$ & - & 0.01 & 0.02 & - \\
\hline $\mathrm{Na}_{2} \mathrm{O}$ & 0.07 & 0.08 & 0.07 & $\mathrm{Na}_{2} \mathrm{O}$ & 0.18 & 0.21 & 0.27 & 0.23 \\
\hline $\mathrm{Cr}_{2} \mathrm{O}_{3}$ & - & - & 0.08 & $\mathrm{Cr}_{2} \mathrm{O}_{3}$ & - & - & 0.06 & - \\
\hline $\mathrm{MnO}$ & 0.02 & 0.06 & 0.12 & $\mathrm{MnO}$ & - & 0.03 & - & - \\
\hline $\mathrm{MgO}$ & 9.74 & 6.53 & 7.36 & $\mathrm{MgO}$ & 1.66 & 1.77 & 0.97 & 0.98 \\
\hline Total & 91.80 & 89.85 & 91.10 & Total & 94.58 & 94.22 & 94.73 & 93.94 \\
\hline $\mathrm{Al}$ & 2.73 & 2.86 & 2.96 & $\mathrm{Al}$ & 4.94 & 4.98 & 4.99 & 5.00 \\
\hline $\mathrm{Fe}$ & 2.41 & 2.73 & 2.38 & $\mathrm{Fe}$ & 0.20 & 0.23 & 0.53 & 0.48 \\
\hline $\mathrm{Ti}$ & 0.26 & 0.37 & 0.37 & $\mathrm{Ti}$ & 0.12 & 0.06 & 0.12 & 0.12 \\
\hline $\mathrm{Si}$ & 5.84 & 5.89 & 5.86 & $\mathrm{Si}$ & 6.42 & 6.43 & 6.28 & 6.30 \\
\hline K & 1.98 & 1.72 & 1.86 & K & 1.90 & 1.90 & 1.88 & 1.93 \\
\hline $\mathrm{Ca}$ & - & 0.02 & 0.01 & $\mathrm{Ca}$ & - & - & - & - \\
\hline $\mathrm{Na}$ & 0.02 & 0.03 & 0.02 & $\mathrm{Na}$ & 0.05 & 0.06 & 0.07 & 0.06 \\
\hline $\mathrm{Cr}$ & - & - & 0.01 & $\mathrm{Cr}$ & - & - & 0.01 & - \\
\hline $\mathrm{Mn}$ & - & 0.01 & 0.02 & $\mathrm{Mn}$ & - & - & - & - \\
\hline $\mathrm{Mg}$ & 2.29 & 1.57 & 1.73 & $\mathrm{Mg}$ & 0.33 & 0.36 & 0.20 & 0.20 \\
\hline Cation & 15.54 & 15.19 & 15.22 & Cation & 13.97 & 14.01 & 14.08 & 14.08 \\
\hline $\mathrm{X}_{\mathrm{Mg}}$ & 0.49 & 0.37 & 0.42 & Paragonite & 0.02 & 0.03 & 0.04 & 0.03 \\
\hline Ti-biotite & 0.13 & 0.18 & 0.19 & Celadonite & 0.18 & 0.20 & 0.13 & 0.14 \\
\hline Talc-minnesotite & - & 0.13 & 0.06 & Pyrophyllite & 0.02 & 0.02 & 0.02 & 0.01 \\
\hline Muscovite & 0.09 & 0.10 & 0.12 & Ti-muscovite & 0.06 & 0.03 & 0.06 & 0.06 \\
\hline Eastonite-siderophyllite & 0.10 & 0.17 & 0.17 & Phlogopite-annite & 0.01 & 0.02 & 0.06 & 0.05 \\
\hline Wonesite & 0.01 & 0.01 & 0.01 & Margarite & - & - & - & - \\
\hline Phlogopite-annite & 0.67 & 0.40 & 0.45 & Muscovite & 0.70 & 0.71 & 0.70 & 0.72 \\
\hline
\end{tabular}


decrease in $\mathrm{TiO}_{2}$ content shown in figure $7(\mathrm{~b})$ indicates formation of tourmaline at the expense of biotite (Sengupta et al. 2005), which is rarely present in this particular rock type. Figure 8(a and b) shows plots for zoned tourmaline from quartz tourmaline veins. This figure shows increase in $\mathrm{MgO}$ and $\mathrm{CaO}$ content from core to rim in the tourmaline grain. The discontinuous boundary among several zones of tourmaline grains (figure $4 \mathrm{k}$ ) is a clear reflection of chemical variation across the zonal boundaries accompanied by increase of $\mathrm{Ca}$ and $\mathrm{Mg}$ and decrease of $\mathrm{Fe}$ corresponding to prograde evolution (Sperlich et al. 1996). This indicates progressive chemical adjustment within a

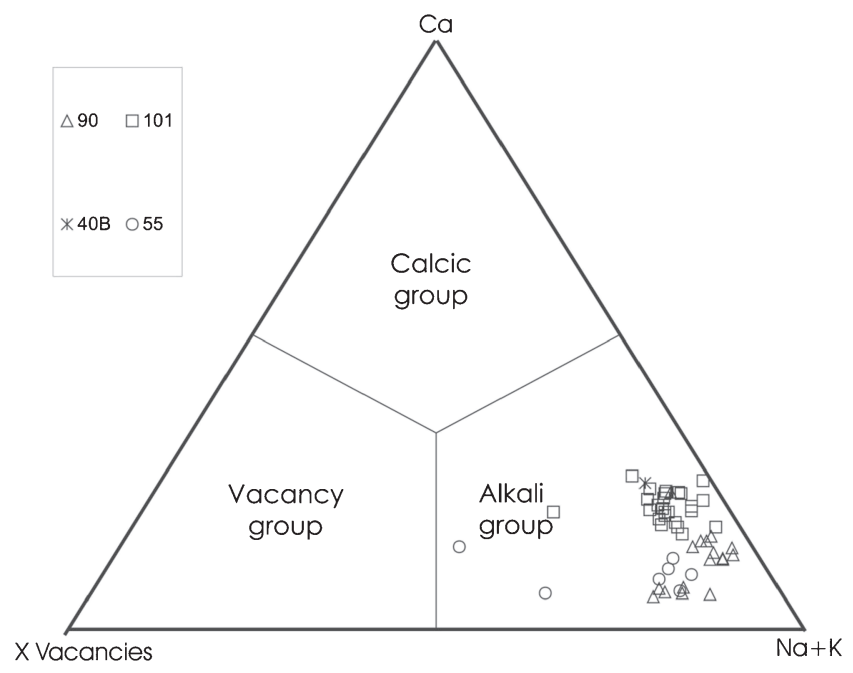

Figure 5. Classification diagram of tourmaline (Hawthorne and Henry 1999) based on apfu calculation. All the tourmalines from different lithotypes fall in the alkali group. \#90: quartz tourmaline rock, \#101: migmatized quartz tourmaline, \#40B: quartz pebble conglomerate, and \#55: migmatized quartz tourmaline. single crystal of tourmaline corresponding to changing metamorphic milieu. Boron content in felsic magmas often plays a vital role in determining stability of tourmaline in equilibrium with biotite and other minerals (Wolf and London 1997). Their experiment brought out the relationship of tourmaline stability to the activity product of tourmaline components, boron and aluminum, which are inversely related to one another. Tourmaline is unstable meta-aluminous to mildly peraluminous melts at $750^{\circ} \mathrm{C}$ regardless of their boron content. It is a favourable notion that most leucogranitic magmas will initially crystallize biotite, cordiarite or garnet and with onset of crytallization-metamorphic re-equilibration, the $\mathrm{Fe}-\mathrm{Mg}$ content in the system decreases and the $\mathrm{B}_{2} \mathrm{O}_{3}$ content increases until tourmaline-biotite equilibrium is attained. The present observation of occurrence of disseminated long accessory tourmaline grains within migmatized quartz tourmaline gneiss commonly reflect their origin at evaluated boron content (London 2011). The initial composition of tourmaline is an important factor in determining the chemical evolution during later stages of metamorphism. The metamorphic evolution is concomitant with changes in chemical parameter (Sperlich et al. 1996). As for example, the $\mathrm{Fe}^{3+} / \mathrm{Fe}^{2+}$ values in tourmaline reached a maximum under greenschist facies condition and then it starts decreasing at the onset of amphibolites facies, similar to the observation made by Frey (1969). In general, the compositional evolution of tourmaline during prograde metamorphism is usually distinct for individual samples. Some general patterns of compositional variations are normally observed. The slight increase of $\mathrm{Mg}$ from core to rim of tourmaline (as in this study) can be attributed to decrease Fe during the progressive

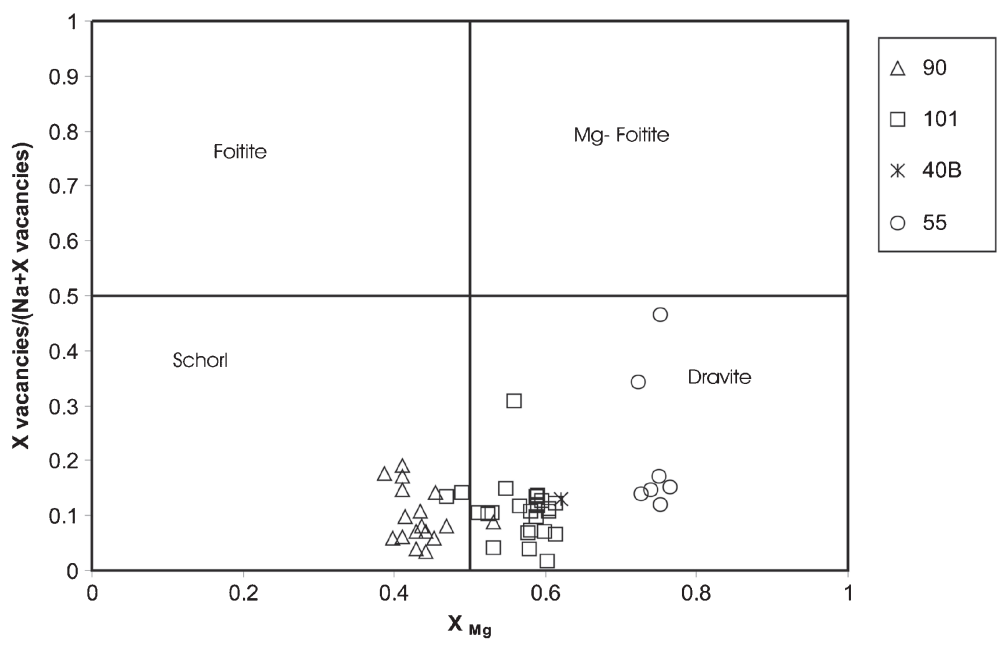

Figure 6. Classification diagram of tourmaline (Henry et al. 2002) based on apfu calculation. Tourmaline from sample no. 90 fall in the field of schorl, whereas tourmalines from rest of the samples fall in the field of dravite. Some data from 101 straddles in the schorl-dravite boundary \#90: quartz tourmaline rock, \#101: migmatized quartz tourmaline, \#40B: quartz pebble conglomerate, and \#55: migmatized quartz tourmaline. 

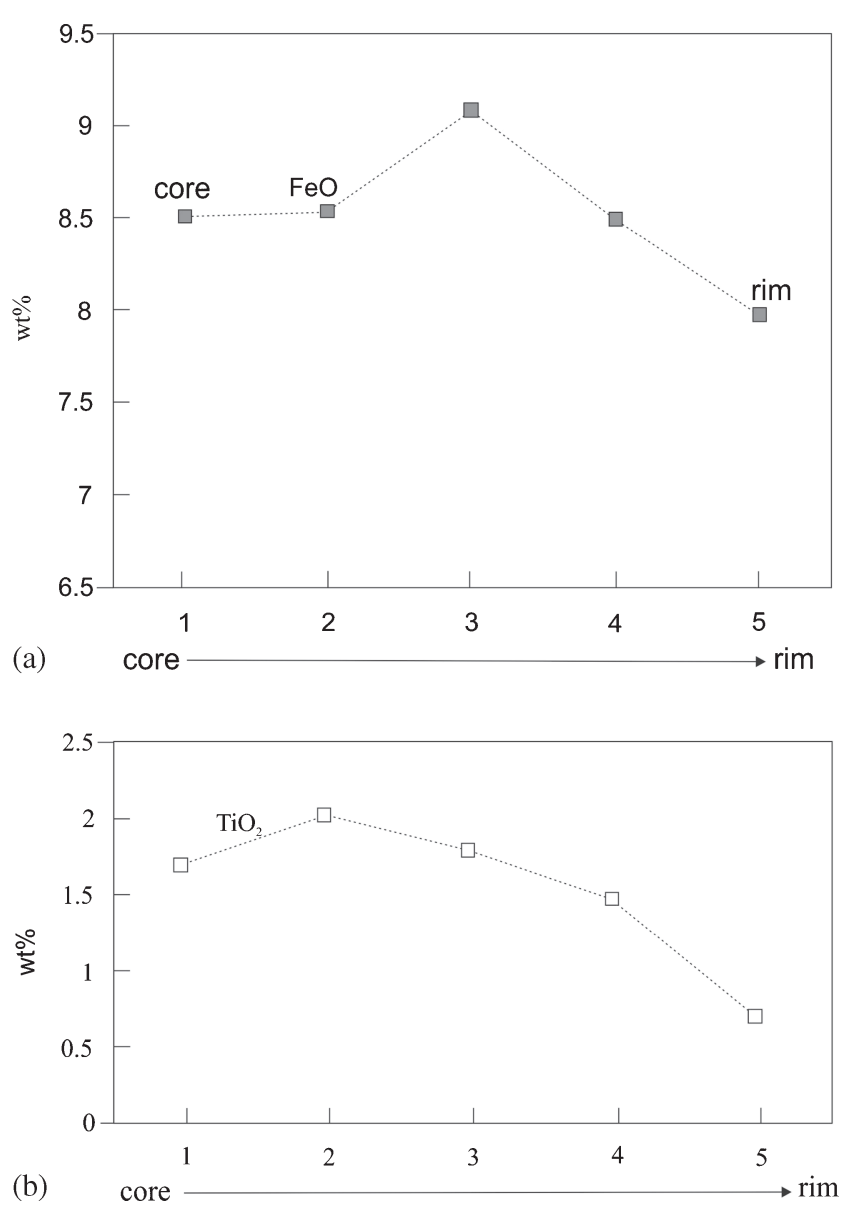

Figure 7. Variation in (a) $\mathrm{FeO}$ and (b) $\mathrm{TiO}_{2}$ content in a tourmaline grain (\#101: quartz tourmaline gneiss) from core to rim. Peaks and valleys in compositional trend indicate zonal boundaries within a single grain. (b) Overall decrease in $\mathrm{TiO}_{2}$ content from core to rim; this may be explained by formation of tourmaline at the expense of biotite.

metamorphism, which is similar to progressive enrichment of $\mathrm{Mg}$ in other ferromagnesian silicates.

Increment of $\mathrm{Ca}$ from core to rim as seen in figure 8 is a clear manifestation of simultaneous decrease of $\mathrm{Na}$ or eventual rise of $\mathrm{Ca} /(\mathrm{Ca}+\mathrm{Na})$. This is a strong support in favour of increasing metamorphic grade (Sperlich et al. 1996). This again indicates progressive chemical variation of $\mathrm{MgO}$ and $\mathrm{CaO}$ corresponding to metamorphic event that is inferred to be prograde.

Chemical compositions of coexisting plagioclase and K-feldspars (from the granite gneiss lithotype; sp. no. 8) have been presented in table 4 . The analyzed plots of orthoclase and plagioclase correspond to the mineralogy of granite gneiss. Two feldspar thermometry using composition of coexisting plagioclase and alkali feldspar (after the method of Stormer 1975) yields a temperature of $400^{\circ}-730^{\circ} \mathrm{C}$ corresponding to assumed pressures of $5 \mathrm{~Kb}$. This temperature conforms well with crystallization of parent granitic magma corresponding to a water rich milieu (Luth et al. 1964; Hazra
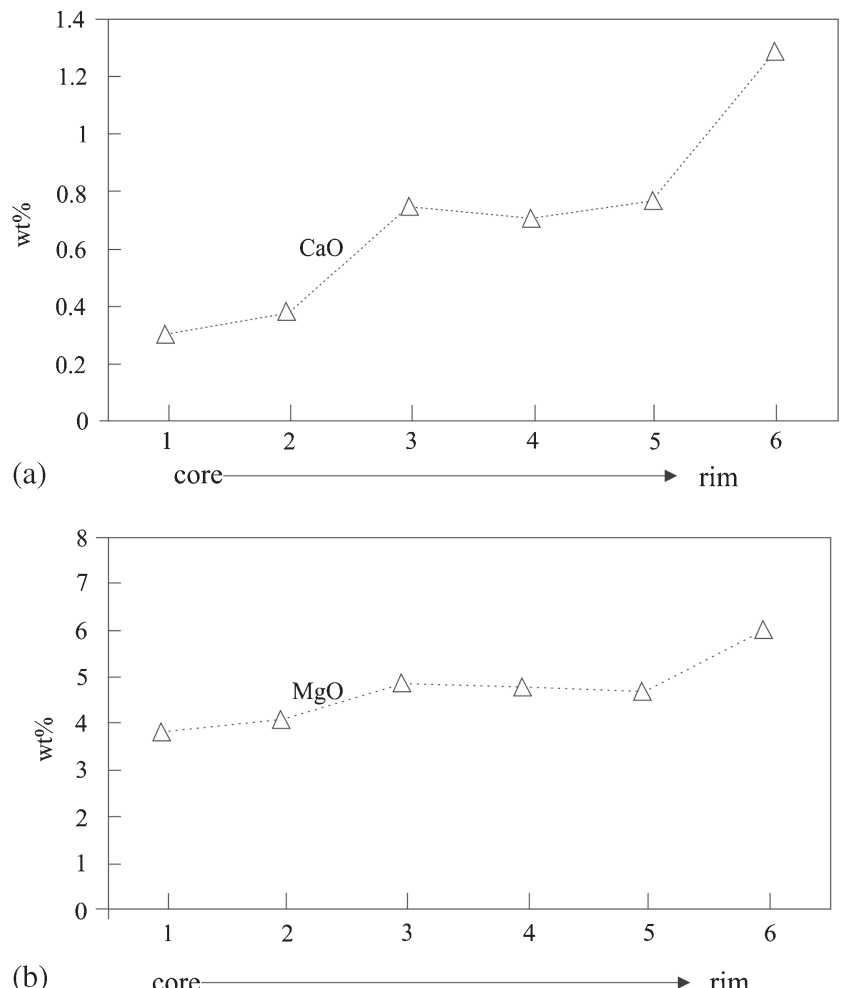

Figure 8. Variation showing increase in (a) $\mathrm{CaO}$ and (b) $\mathrm{MgO}$ content from core to rim in the tourmaline grain from quartz tourmaline veins.

et al. 2010). Chemical compositions of phyllosilicate minerals (from granite gneiss: sp. no. 8 and quartz pebble conglomerate: sp. no. 40B) have been presented in table 5 .

\section{Summary and discussion}

Composition of studied tourmaline straddles between schorl and dravite varieties depends on their petrographic types. Schorl-dravite transition for tourmalines is a widely accepted feature and has been documented by Federico et al. (1998) from Minas Gerais, Brazil. Present investigation clearly brings out occurrence of tourmaline in lowmedium grade metamorphic assemblage (or metasomatically affected migmatized quartz tourmaline gneisses) rocks; and similar situation has been described from Sierra Nevada (Torres-Ruiz et al. 2003) and Variscan Granite (Neiva et al. 2007). The distribution and geometry of tourmalinebearing rock units are thought to be reflection of boron and water availability in metasedimentary rocks during anatexis, variable oxygen fugacity $\left(\mathrm{fo}_{2}\right)$, and restricted mobility of mafic cation (Gaweda et al. 2002).

The SPSZ is associated with polyphase deformation as deduced by several researchers (Bhattacharyya et al. 1992; Sengupta et al. 2005). 
It needs to be mentioned here that occurrences of tourmalinite all along the SSZ (running parallel to the presently studied SPSZ) have been reported by previous researchers (Deb and Mukhopadhyay 1991; Bhattacharyya et al. 1992; Sengupta et al. 2005). The occurrence of tourmaline associated with migmatized terrane has been reported from elsewhere in the world (Markl and Bucher 1998; Kawakami 2001). Mineral-chemical studies on tourmaline clearly indicate that tourmaline grains corresponding to different stages of shear zones reflect a discernible chemistry. The tourmaline crystals developed corresponding to earlier shear zone (later migmatized) are clearly dravitic while those related to later shear zones (manifested in quartz-tourmaline veins) are schorlitic (figure 5). It has been found from experimental findings (Benard et al. 1985) that composition of tourmaline growing from the melt changes from more Mg-rich (dravitic) at high temperature to more Fe-rich tourmaline (schorlitic) at lower temperature. Thus, formation of dravitic and schorlitic tourmalines is in conformity with development of earlier and later shear zones in this area.

The variations in elemental oxide patterns developed in single crystal of tourmaline clearly correspond to zoning in the crystals being controlled by varying metamorphic milieu in the region. Similar to that of present occurrence, tourmalines are associated with strata-bound deposits, related to ortho-amphibolite in eastern Sierras Pampeanas, Argentina (Tourn et al. 2004). In the Sierras Pampeanas locality, tourmalines are found to be located in biotite schist stratigraphically related to acid and intermediate meta-volcanic rocks and scheelite-bearing quartzite. Tourn et al. (2004) envisaged tungsten and boron in quartz veins deposit being re-mobilized from strata-bound horizons by liquid state transfer activated by regional shear zone. Similar occurrence of strata-bound shear zone controlled (Nugrus Shear Zone) mineralization from Saikait area of south eastern desert of Egypt has been described by Harraz and ElSharkawy (2001). They have also described discontinuous tourmaline band within the meta-pelitic rocks, pegmatite and quartz veins.

It is an important point to state that the chemistry of the tourmaline from granitoid bodies of different parts of Indian Shield has been presented by several researchers, as for example, the Gangotri Granite $(23 \pm 0.2 \mathrm{Ma})$ is one of the largest leuco-granite belts occurring in Garwhal Higher Himalaya. Tourmaline occurs as accessory within granite body belonging to alkali group and specifically it corresponds to schorl varieties (Jowhar 2010). Boron isotopic and chemical compositions of tourmaline from the gold deposits within the Archean Hutti-Muski greenstone belt in southern India were carried out in order to constrain evolution of hydrothermal system and fluid sources (Krienitz et al. 2008). The tourmalines have dravite-schorl composition; while the boron isotopic composition clearly indicates the tourmaline requires at least two isotopically distinct fluid sources for its origin. Out of these two fluids, the isotopically lighter one is consistent with boron released by metamorphic devolatilization reaction from the greenstone lithology, whereas ${ }^{11} \mathrm{~B}$-rich fluid is attributed to degassing of I-type granitic magmas that intruded greenstone belt providing heat and fluid to the hydrothermal system (Krienitz et al. 2008). It has been agreed upon by the researchers like Borg et al. (1997), Benton et al. (2001), Leeman et al. (2004) and Ota et al. (2008) that fluid mobile elements (FMEs) apparently were reduced extensively before the slab reached sub-arc depth and essentially depleted as it moved beneath the back arc and also a small amount of boron infiltrates beneath the frontal arc. Hence, in the present scenario, infiltration of boron might have taken place in a subduction-shear zone induced earthquake regime during protoplate movement.

Strongly zoned tourmaline has been illustrated by Nakano and Nakamura (2001) and Marshall et al. (2008), where $\mathrm{Mg}$ contents steadily increases from core to rim due to tourmaline growth during increasing temperature. This has been explained by preferential release of boron from mica and transportation of the same via fluid along grain boundaries and subsequent concentration in tourmaline cores. This spatially associated remaining mica is isotopically higher and releases B with progressively lower $\delta^{11}$ value into fluid during further heating. It is also possible here that the boron-rich fluid is attributed to degassing of I-type granitic magma.

Various combinations of exchange vectors in zones of tourmaline play important role to define the nature of substitution in terms of crystal chemistry (Henry and Dutrow 1990). Based on initial, intermediate and final composition of zoned tourmaline crystals, relevant exchange vectors can be determined directly (Hewitt and Abrecht 1986). However, the accuracy of the nature of exchange vectors can be made more authenticated if those can be synthesized experimentally (Abrecht and Hewitt 1988). The normal trend of Ca, substituting $\mathrm{Na}$ results in development of complementary coupled substitution (Foit and Rosenberg 1977). Normally, the vector representations provide a simple graphical depiction of charge restriction (without reference to stability under particular condition of crystallization). Usually, more plausible exchange vector in terms of crystal chemistry can be assessed using data from zoned Ca bearing tourmaline crystals in a graphical prism (Henry and Dutrow 1990). 
In fact, compositional variation in minerals associated with the tourmaline reflects the polymetamorphic nature of the sample. It is therefore proposed here that different types of tourmaline recorded in the study area is the result of complex inter-play of shear-induced boron-enriched fluid infiltration and prograde metamorphic milieu and chemical factors like oxygen fugacity, migration of cation and ex-solution of boron-rich fluid phase.

\section{Acknowledgements}

The authors are thankful to the authorities of the Atomic Minerals Division for their kind help during the field-work. Authors are also grateful to the anonymous journal-reviewer for his critical comments to upgrade the quality of the paper. Ms. Sonia Sarkar is acknowledged for the technical assistance.

\section{References}

Abrecht J and Hewitt D A 1988 Experimental evidence on the substitution of Ti in biotite; Am. Mineral. 73 12751284 .

Baidya T K and Chakravarty P S 1988 Mineralisation in the Belemu-Jaipur sector of north western Purulia district, West Bengal; In: Precambrian of the Eastern Indian Shield, India (ed.) Mukhopadhyay D, Geol. Soc. Memoir 8 147-165.

Benard F, Moutou P and Pichavant M 1985 Phase relations of tourmaline leucogranites and the significance of tourmaline in silicic magmas; J. Geol. 93 271-291.

Benton L D, Ryan J G and Tera F 2001 Boron isotope systematics of slab fluids as inferred from a serpentine seamount, Mariana forearc; Earth Planet. Sci. Lett. 187 $273-282$.

Bhattacharyya H N, Chatterjee A and Chowdhury S 1992 Tourmalinite from $\mathrm{Cu}-\mathrm{U}$ belt of Singhbhum, Bihar, India; J. Geol. Soc. India 39 191-195.

Borg L E, Clynne M A and Bullen T D 1997 The variable role of slab-derived fluids in the generation of a suite of primitive calc-alkaline lavas from the southernmost cascades, Calilornia; Can. Mineral. 35 425-452.

Das D K 1977 A brief resume of mineral investigation at Purulia with a proposal; J. Mines Met. Fuels Spec. Publ. (Purulia Symp), Spec. No. 45-49.

Dasgupta S et al. 2000 Seismotectonic Atlas of India and its environs (eds) Narula P L et al., Geol. Surv. India.

Deb G and Mukhopadhyay D 1991 An occurrence of tourmalinite along Singhbhum shear zone; Ind. Mins. 45 313-318.

Dutrow B L, Foster C T and Henry D J 1999 Tourmalinerich pseudomorphs in sillimanite zone metapelites: Demarcation of an infiltration front; Am. Mineral. 84 794-805.

Fareeduddin Gupta S, Golani P R, Kirmani I R and Chander S 2010 Tourmaline as metallogenic Indicator: Examples from Paleo-Proterozoic $\mathrm{Pb}-\mathrm{Zn}$ and $\mathrm{Cu}-\mathrm{Au}$ deposits of Rajasthan; J. Geol. Soc. India 76 215-243.

Federico M, Andreozzi G B, Luccesi S, Graziani G and Mendes J C 1998 Composition variation of tourmaline in the granitic pegmatite dykes of the Cruzeiro Mine, Minas Gerais, Brazil; Can. Mineral. 36 415-431.
Foit F F Jr and Rosenberg P E 1977 Coupled substitution in the tourmaline group; Contrib. Mineral. Petrol. 62 109-127.

Freund F, da Silva M A S, Lau B W S, Takeuchi A and Jones H H 2007 Electric currents along earthquake faults and the magnetization of pseudotachylite veins; Tectonophys. 431 131-141.

Frey M 1969 Die metamorphosed des Keupers vom Tafeljura bis zum Lukmanier-Gebiet; Beitrige zur Geologischen Karte der Schweiz, Neue Folge, 137p.

Gaweda A, Pieczka A and Kraczka J 2002 Tourmaline from the western Tatra Mountain (W-Carpathians, S-Poland): Their characteristic and petrogenetic importance; Euro. J. Mineral. 14 943-955.

Harraz H Z and El-Sharkawy M F 2001 Origin of tourmaline in the metamorphed Sikait pelitic belt, south eastern Desert, Egypt; J. African Sci. 33 391-416.

Hazra S, Saha P, Ray J and Podder A 2010 Simple statistical and mineralogical studies as petrogenetic indicator for neoproterozoic Mylliem porphyritic granites of east Khasi Hills, Meghalaya, northeastern India; J. Geol. Soc. India 75 760-768.

Hawthorne F J and Henry D J 1999 Classification of the minerals of the tourmaline group; Euro. J. Miner. 11 201-216.

Henry D J and Dutrow B L 1990 Ca substitution in Li-poor aluminous tourmaline; Can. Mineral. 28 111-124.

Henry D J and Guidotti C V 1985 Tourmaline as a petrogenetic indicator mineral - An example from the staurolite-grade metapelites of NW Maine; Am. Mineral. $701-15$.

Henry D J, Dutrow B L and Selverstone J 2002 Compositional asymmetry in replacement tourmaline - An example from the Tauern Window, Eastern Alps; Geol. Soc. Am. Spec. Vol. 4 1-18.

Hewitt D A and Abrecht J 1986 Limitation on the interpretation of biotite substitutions from chemical analyses of natural samples; Am. Mineral. 71 1126-1128.

Hinsberg V J V and Schumacher J C 2009 The geothermobarometric potential of tourmaline, based on experimental and natural data; Am. Mineral. 94 761-770.

Holdaway M J, Durnow B L and Hinton R W 1988 Devonian and Carboniferous metamorphism in west-central Maine: The muscovite-almandine geobarometer and the staurolite problem revisited; Am. Mineral. 73 20-47.

Jowhar T N 2010 Chemistry of tourmalines from the Gangotri Granite, Garhwal Higher Himalaya; Earth Sci. India 3 181-194.

Kawakami T 2001 Tourmaline breakdown in the migmatite zone of the Ryoke metamorphic belt, SW Japan; J. Metamor. Geol. 19 61-75.

Kerrich R 1986 Fluid transport in lineaments; Phil. Trans. Roy. Soc. London A/317 219-251.

Krienitz M S, Trumbull R B, Hellmann A, Kolb J, Meyer F M and Wiedenbeck M 2008 Hydrothermal gold mineralization at the Hira Buddini Gold Mine, India: Constraints on fluid sources and evolution from boron isotopic compositions of tourmaline; Min. Deposita 43(4) 421-434.

Kumar M N and Dasgupta S 1985 Gold mineralisation along the North Shear Zone, Purulia Dist., West Bengal - An up-to-date appraisal; Rec. Geol. Surv. India 113(3) 25-32.

Leech M L, Shulman D and Dutra S 2009 Pseudotachylite in eclogite-facies shear zones from the Lofoten Islands, northern Norway; In: AGU Fall Meeting Abstracts 1, 2265.

Leeman W P, Tonarini S, Chan L H and Borg L E 2004 Boron and lithium isotopic variations in a hot subduction zone - the southern Washington cascades; Chem. Geol. 212 101-124. 
London D 1986 Magmatic-hydrothermal transition in the Tanco rare-element pegmatite; evidence from fluid inclusions and phase-equilibrium experiments; Am. Mineral. $71376-395$.

London D 2011 Experimental synthesis and stability of tourmaline: A historical overview; Can. Mineral. 49 $117-136$.

London D, Hervig R L and Morgan G B VI 1988 Melt-vapor solubilities and elemental partitioning in peraluminous granite-pegmatite systems: Experimental results with Macusani glass at $200 \mathrm{MPa}$; Contrib. Mineral. Petrol. 99 360-373.

Luth W C, Jahns R H and Tuttle O F 1964 The granite system at pressures of 4 to 10 kilobars; J. Geophys. Res. $69759-773$.

Mahadevan T M 1992 Geological evolution of the Chhotanagpur Gneissic Complex in a part of Purulia District, West Bengal; Ind. J. Geol. 64(1) 1-22.

Markl G and Bucher K 1998 Composition of fluids in the lower crust inferred from metamorphic salt in lower crustal rocks; Nature 391 781-783.

Marshall H R, Altherr R, Kalt A and Ludwig T 2008 Detrital metamorphic and metasomatic tourmaline in highpressure metasediments from Sycos (Greece): Intra-grain boron isotope patterns determined by secondary ion mass spectrometry; Contrib. Mineral. Petrol. 155 703-717.

Mc Caig A M 1989 Fluid flow through fault zones; Nature 340600.

Nakano T and Nakamura E 2001 boron isotope geochemistry of metasedimenatry rock and tourmalines in a subduction zone metamorphic suit; Phys. Earth Planet. Inter. 127 $233-252$.

Neiva A M R, Silva M V G and Gomes M E P 2007 Crystal chemistry of tourmaline from Variscan granite, associated tin-tungsten-gold deposits, and associated metamorphic and metasomatic rocks from northern Portugal; N. Jb. Miner. Abh. 184/1 45-76.

Numan M N and Tracy R J 1993 Petrological evolution of amphibolite shear zone, Cheyene Belt, South East Wyoming, USA; J. Metamor. Geol. 11 757-773.

Ota T, Kobayashi K, Kunihiro T and Nakamura E 2008 boron cycling by subducted lithosphere; insights from diamondiferous tourmaline from the Kokchetav ultra highpressure metamorphic belt; Geochim. Cosmochim. Acta $723531-3541$.

Saha A K 1988 Some aspects of the crustal growth of the Singbhum-Orissa Iron Ore Craton, eastern India; Ind. J. Geol. 60 207-278.

Saha A K 1994 Crustal evolution of Singhbhum-North Orissa, Eastern India; Geol. Soc. India Memoir 27 341p.
Sarkar D N 1977 Barite deposits of Purulia district with special reference to the occurrence in Jhalda area, West Bengal; J. Mines Metals Fuels Purulia Seminar, Spec. No. 239-241.

Sarkar S N and Saha A K 1983 Structure and tectonics of the Singhbhum-Orissa Iron-Ore Craton, eastern India; Recent Researches in Geology, Hindustan Publ. Corp. India, 10 $1-25$.

Sarkar S N and Saha A K 1997 The present status of the Precambrian of Singbhum-Keonjhar-Mayurbhanj region, eastern India; Indian J. Earth Sci. 5 37-65.

Sarkar P, Bandyopadhyay K C, Ghosh Roy A and Mukhopadhyay G 1993 On occurrence of allanitebastnaesite and pollucite in the Chhotanagpur gneissic complex, Purulia district, West Bengal; Indian Minerals 47(3) 237-242.

Sengupta N, Mukhopadhyay D, Sengupta P and Hoffbauer $\mathrm{R} 2005$ Tourmaline bearing rocks in the Singhbhum Shear Zone, eastern India: Evidence of boron infiltration during regional metamorphism; Am. Mineral. 90 12411255 .

Som S K, Bhandyopadhyay K C, Santra D K and Ghosh R N 2002 Li-Cs-Rb mineralization in Proterozoic zoned pegmatites of Beku, West Bengal; J. Geol. Soc. India 60 493-503.

Sperlich R, Giert R and Frey M 1996 Evolution of compositional polarity and zoning in tourmaline during prograde metamorphism of sedimentary rocks in the Swiss Central Alps; Am. Mineral. 81 1222-1236.

Stormer Jr J C 1975 A practical two-feldspar geothermometer; Am. Mineral. 60 667-674.

Thorpe R S 1987 Pseudotachylite from a Precambrian shear zone in the Malvern Hills; Proc. The Geologists' Association 98 205-210.

Torres-Ruiz J, Pesquera A, Gil-Grespo P P and Velilla N 2003 Origin and petrogenetic implication of tourmalinerich rocks in the Sierra Nevada (Betic Cordillera, southeastern Spain); Chem. Geol. 197 55-86.

Tourn S M, Herrmann C J, Ametrano S and De-brodtkorb M K 2004 Tourmalinites from the eastern Sierras Pampeanas, Argentina; Ore Geol. Rev. 24 229-240.

Urai J L and Humphreyes F J 1981 The development of shear folds in polycrystalline camphor; Tectonophys. $\mathbf{7 8}$ 677-685.

White S H, Burrows S E, Carrera J, Shaw N D and Humphreyes F J 1980 On mylonites in ductile shear zone; J. Struct. Geol. 2 175-187.

Wolf M B and London D 1997 Boron in granitic magmas: Stability of tourmaline in equilibrium with biotite and cordierite; Contrib. Mineral. Petrol. 130 12-30. 